\title{
Spatial and temporal variability of snow accumulation in East Antarctica from traverse data
}

\author{
Massimo FREZZOTTI, ${ }^{1}$ Michel POURCHET, ${ }^{2}$ Onelio FLORA, ${ }^{3}$ Stefano GANDOLFI, ${ }^{4}$ \\ Michel GAY, ${ }^{2}$ Stefano URBINI, ${ }^{5}$ Christian VINCENT, ${ }^{2}$ Silvia BECAGLI, ${ }^{6}$ \\ Roberto GRAGNANI, ${ }^{1}$ Marco PROPOSITO, ${ }^{1}$ Mirko SEVERI, ${ }^{6}$ Rita TRAVERSI, ${ }^{6}$ \\ Roberto UDISTI, ${ }^{6}$ Michel FILY ${ }^{2}$ \\ ${ }^{1}$ ENEA, Centro Ricerche Casaccia, PO Box 2400, I-00100, Rome, Italy \\ E-mail: frezzotti@casaccia.enea.it \\ ${ }^{2}$ Laboratoire de Glaciologie et Géophysique de l'Environnement, CNRS-UJF, 54 rue Mollère, BP 96, \\ 38402 Saint-Martin-d'Hères Cedex, France \\ ${ }^{3}$ Dipartimento di Scienze Geologiche, Ambientali e Marine, Università di Trieste, Via E. Weiss 6, Trieste, Italy \\ ${ }^{4}$ DISTART, Università di Bologna, Viale Risorgimento 2, 1-40B6 Bologna, Italy \\ ${ }^{5}$ Istituto Nazionale di Geofisica e Vulcanologia, Via de Vigna Murata 605, I-00143 Rome, Italy \\ ${ }^{6}$ Dipartimento di Chimica, Università degli Studi di Firenze, Via della Lastruccia 3, I-50019 Sesto Fiorentino (Florence), Italy
}

\begin{abstract}
Recent snow accumulation rate is a key quantity for ice-core and mass-balance studies. Several accumulation measurement methods (stake farm, fin core, snow-radar profiling, surface morphology, remote sensing) were used, compared and integrated at eight sites along a transect from Terra Nova Bay to Dome C, East Antarctica, to provide information about the spatial and temporal variability of snow accumulation. Thirty-nine cores were dated by identifying tritium $/ \beta$ marker levels (1965-66) and non-sea-salt (nss) $\mathrm{SO}_{4}{ }^{2-}$ spikes of the Tambora (Indonesia) volcanic event (1816) in order to provide information on temporal variability. Cores were linked by snow radar and global positioning system surveys to provide detailed information on spatial variability in snow accumulation. Stake-farm and ice-core accumulation rates are observed to differ significantly, but isochrones (snow radar) correlate well with ice-core derived accumulation. The accumulation/ablation pattern from stake measurements suggests that the annual local noise (metre scale) in snow accumulation can approach 2 years of ablation and more than four times the average annual accumulation, with no accumulation or ablation for a 5 year period in up to $40 \%$ of cases. The spatial variability of snow accumulation at the kilometre scale is one order of magnitude higher than temporal variability at the multi-decadal/secular scale. Stake measurements and firn cores at Dome C confirm an approximate $30 \%$ increase in accumulation over the last two centuries, with respect to the average over the last 5000 years.
\end{abstract}

\section{INTRODUCTION}

Antarctica is the highest and flattest of the Earth's continents, but small changes in slope have a strong impact on wind direction and speed (Frezzotti and others, 2002a). It is well known that slope and curvature play an important role in the accumulation of snow; for example, concave depressions accumulate snow relative to convex bumps (Black and Budd, 1964; Whillans, 1975; Pettré and others, 1986; Van den Broeke and others, 1999; Liston and others, 2000; Frezzotti and others, 2002a). A large area of the polar plateau, where the slope along the wind direction is larger than $4 \mathrm{~m} \mathrm{~km}^{-1}$, has a nil or slightly negative snow accumulation (Frezzotti and others, 2002b).

The spatial scale of significance for a single ice-core record is a critical point in stratigraphic interpretation itself. Micro-relief introduces a high-frequency, quasi-stochastic variability into ice-core records of annual layer thickness (Fisher and others, 1985; Van der Veen and Bolzan, 1999).

The stratigraphic record of an ice core is affected by the flow of ice, so the material at depth is slowly moved away from the original deposition site. Richardson and Holmlund (1999) demonstrate the importance of determining the spatial significance of cores and recommend radar surveys prior to drilling. Snow radar is the most useful tool for detecting spatial snow accumulation variability, and firncore time series have the best temporal resolution. Accumulation variability along the radar profile can be derived using both datasets.

Ablation processes on short (metre) and long (kilometre) spatial scales have a significant impact on post-depositional losses of chemical species by re-emission (Waddington and Cunningham, 1996; Wagnon and others, 1999) and on the interpretation of ice-core palaeoclimatic time series (Fisher and others, 1985). Interpretation and dating of palaeoenvironmental records extracted from Antarctic ice cores depends on the knowledge of past accumulation changes (e.g. Bromwich and Weaver, 1983; Jouzel and others, 1983).

As part of the ITASE (International Trans-Antarctic Scientific Expedition) project (Mayewski and Goodwin, 1999) and in the framework of the Franco-Italian Concordia Station collaboration, a traverse between Terra Nova Bay (TNB) and Dome C (DC), and research at DC were undertaken between 1998 and 2000. The study aimed to better understand latitudinal and longitudinal environmental gradients, while documenting climatic, atmospheric and surface conditions over the last 200-1000 years in the eastern and northeastern portions of the DC drainage area and in northern Victoria Land. The traverse (Frezzotti and Flora, 2002) started from GPS1 (74 50.04’ S $\left.160^{\circ} 48.03^{\prime} \mathrm{E}\right)$ on 


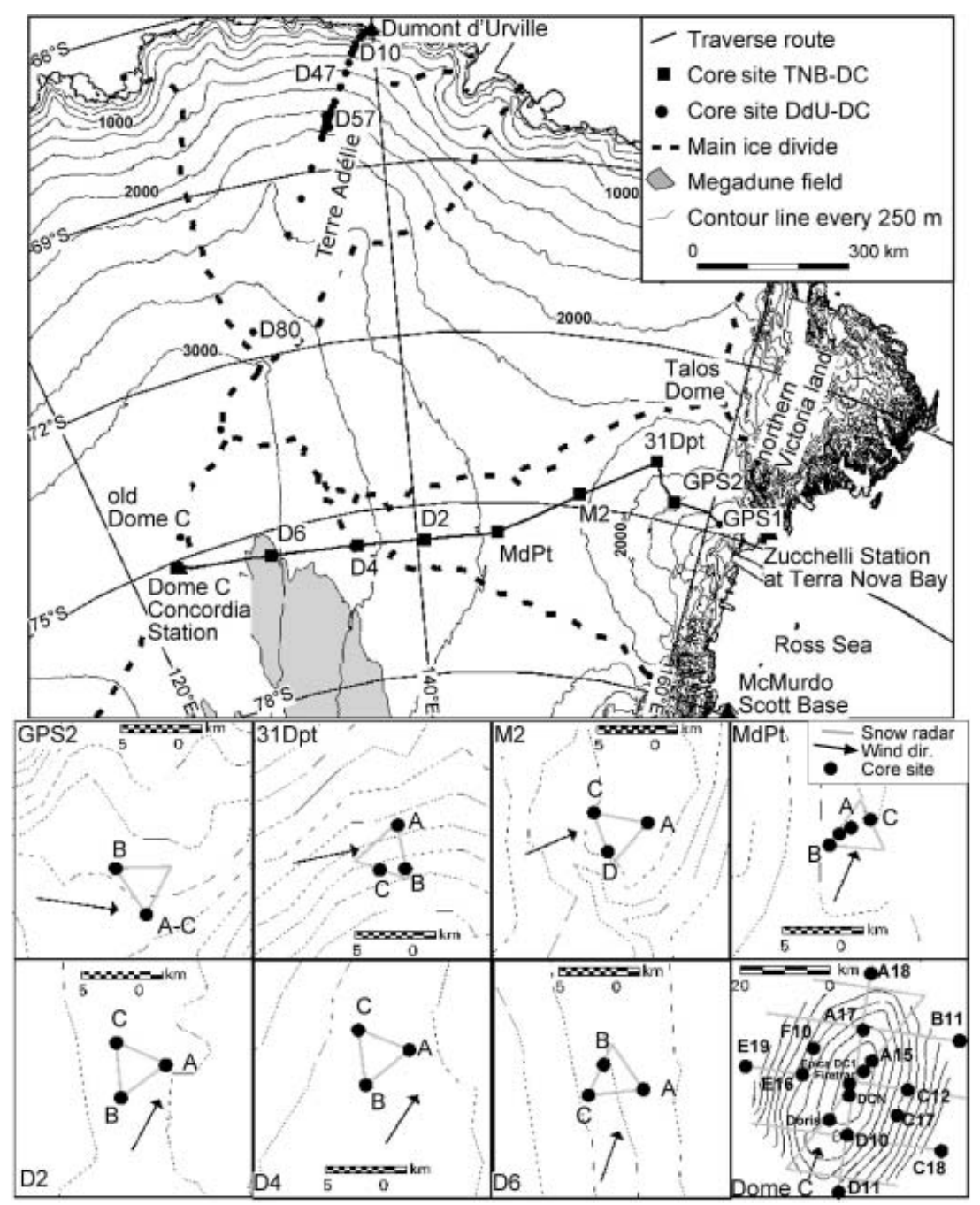

Fig. 1. Schematic map of the traverse from TNB to DC and site locations, and detailed maps of drill sites (contour every $10 \mathrm{~m}$ for GPS2, 31Dpt, M2, MdPt, D2, D4, D6, from Rémy and others, 1999); contour every $1 \mathrm{~m}$ for DC, from Capra and others (2000); prevalent wind direction from Frezzotti and others (2002b).

19 November 1998, reaching Concordia Station at DC $\left(75^{\circ} 06^{\prime} \mathrm{S} 123^{\circ} 23^{\prime} \mathrm{E}, 3232 \mathrm{~m}\right)$ on 5 January 1999; a distance of $1300 \mathrm{~km}$ was covered (Fig. 1). The party performed several tasks (drilling, glaciological and geophysical exploration, etc.) during the traverse (Frezzotti and Flora, 2002; Gay and others, 2002; Proposito and others, 2002; Becagli and others, 2003; Traversi and others, 2004). GPR (ground penetrating radar or snow radar), GPS (global positioning system) and snow morphology surveys were carried out regularly along the traverse (Frezzotti and others, 2002a, b). In addition, shallow ice cores were drilled within a $25 \mathrm{~km}$ radius of Concordia Station between 15 and 25 December 1999 (Vincent and Pourchet, 2000). In 2000, GPR and GPS surveys, covering a total distance of about $500 \mathrm{~km}$, were used to link all core sites to DC in order to provide detailed information on the spatial variability of snow accumulation.

This paper combines geophysical surveys (GPR and GPS), field and remote-sensing surface observations, and firn-core analyses to describe the snow accumulation variability at seven locations along the traverse and at DC. It also provides new information on the snow accumulation process and discusses implications for palaeoclimatic series from ice cores. Using these data, Frezzotti and others (2004) provide new information on the surface mass-balance process and implications for surface mass-balance distribution and variability.

\section{METHODOLOGY}

Twenty-three shallow snow-firn cores, up to $53 \mathrm{~m}$ deep, were drilled during the traverse at eight sites between TNB and DC (at intervals of $90-150 \mathrm{~km}$ ); 16 more were drilled at DC using an electromechanical drilling system (Table 1). At seven sites a 43-53 m deep 'main core' was drilled at the site camp and two 7-15 m deep 'secondary cores' were drilled $5-7 \mathrm{~km}$ away. The location of the secondary sites was identified in the field after a detailed GPS-GPR profile along a $15 \mathrm{~km}$ triangular track (Fig. 1). Data processing in the field was used to identify variability in the internal layering of the snowpack. Snow temperature profiles, down to $30 \mathrm{~m}$ depth, were measured at main core sites after a 15-24 hour equilibration period (Frezzotti and Flora, 2002). Snow/firn density was determined immediately after retrieval by measuring and weighing core sections. Snow was poorly sintered in the uppermost layers; density was thus measured in a pit (close to main core and stake farm) where stratigraphic studies and snow sampling were also performed (Gay and others, 2002). 
Table 1. Location, morphological and climatological characteristic of drill sites; snow accumulation from stake farms, core analyses, and comparison with GPR data (GPR_SA). GPR_SA value are reported as snow accumulation using the depth/age ratio from the 'main' core Tritium snow accumulation (Tambora for D4) and depth in \% respect to the maximum depth of layering used for the statistical analysis. Katabatic wind speed from Parish and Bromwich (1991)

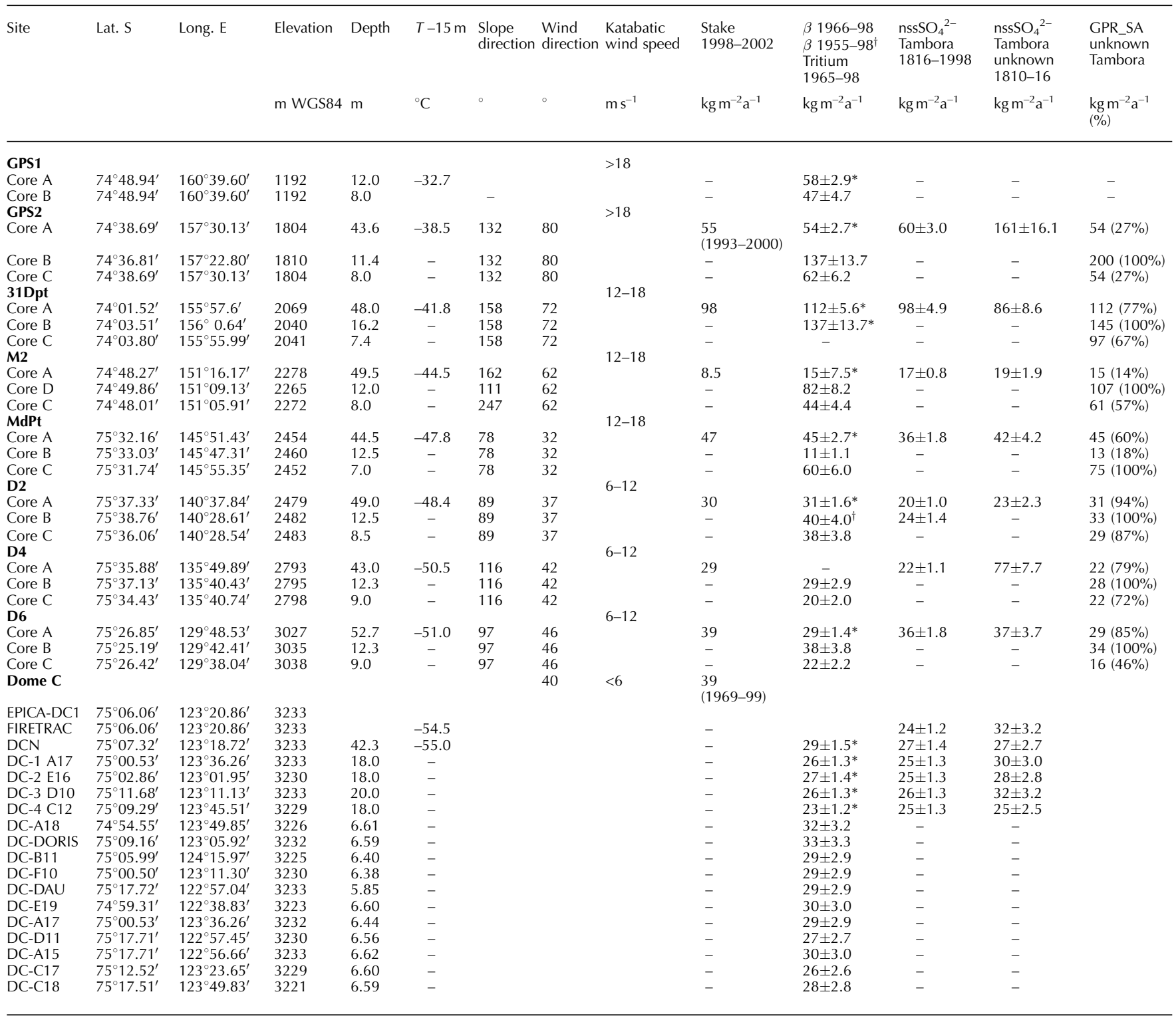

Two reference tritium peak levels resulting from 1965 and 1966 thermonuclear atmospheric bomb tests (Picciotto and others, 1971; Jouzel and others, 1979) and the volcanic sulphate signals of the Tambora (Indonesia) eruption (AD 1815) and of an unknown volcanic event (AD 1809) were used to determine the mean accumulation rate at the 'main' cores along the traverse and at DC (Table 1). Tritium depth profiles were transformed into time series by comparing them with the tritium content of precipitation at the Kaitoke (New Zealand) International Atomic Energy Agency station. In Antarctic ice cores the peaks in $\mathrm{SO}_{4}{ }^{2-}$ signatures of Tambora and unknown are dated 1816 and 1810, and represent the most reliable volcanic markers for dating the last two centuries (e.g. Legrand and Delmas, 1987; Dai and others, 1991; Cole-Dai and others, 1997; Udisti and others, 2000; Stenni and others, 2002). The volcanic signal was obtained from sulphate profiles. No correction for sea-salt sulphate was made because its contribution is always $<15 \%$ (Becagli and others, 2003). Analytical procedures for chemical and tritium measurements are described in detail elsewhere (Udisti and others, 1994; Gragnani and others, 1998; Stenni and others, 2002).

The $\beta$-radioactive reference horizons of January 1955 and January 1965 were used to determine the mean accumulation rate from 'secondary' cores along the traverse and from $6 \mathrm{~m}$ deep cores at DC (Table 1), using methods described in Pourchet and others (1983).

The experimental error $\left( \pm \sigma_{\mathrm{e}}\right)$ in the calculated snow accumulation rates for the different periods is estimated to be of the order of $<10 \%$ for $\beta$ radioactivity (1955/65-98), about $10 \%$ for the unknown-Tambora period (1810-16) and $<5 \%$ for the tritium (1966-98) and Tambora-present (1816$1998)$ periods. These values take into account the different sources of error linked to density determination and the sampling resolution (20-40 cm for $\beta, 3-5 \mathrm{~cm}$ for tritium, 2.5$4 \mathrm{~cm}$ for $\mathrm{SO}_{4}{ }^{2-}$ ).

At seven locations, farms consisting of 40 stakes, centred on the main core site, were geometrically positioned about 

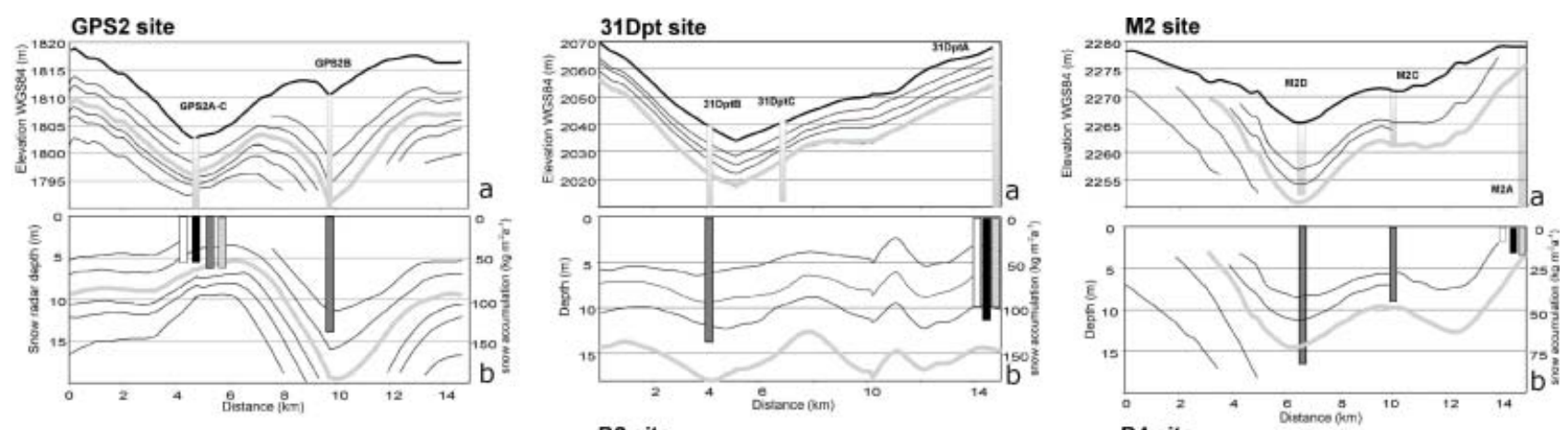

MdPt site
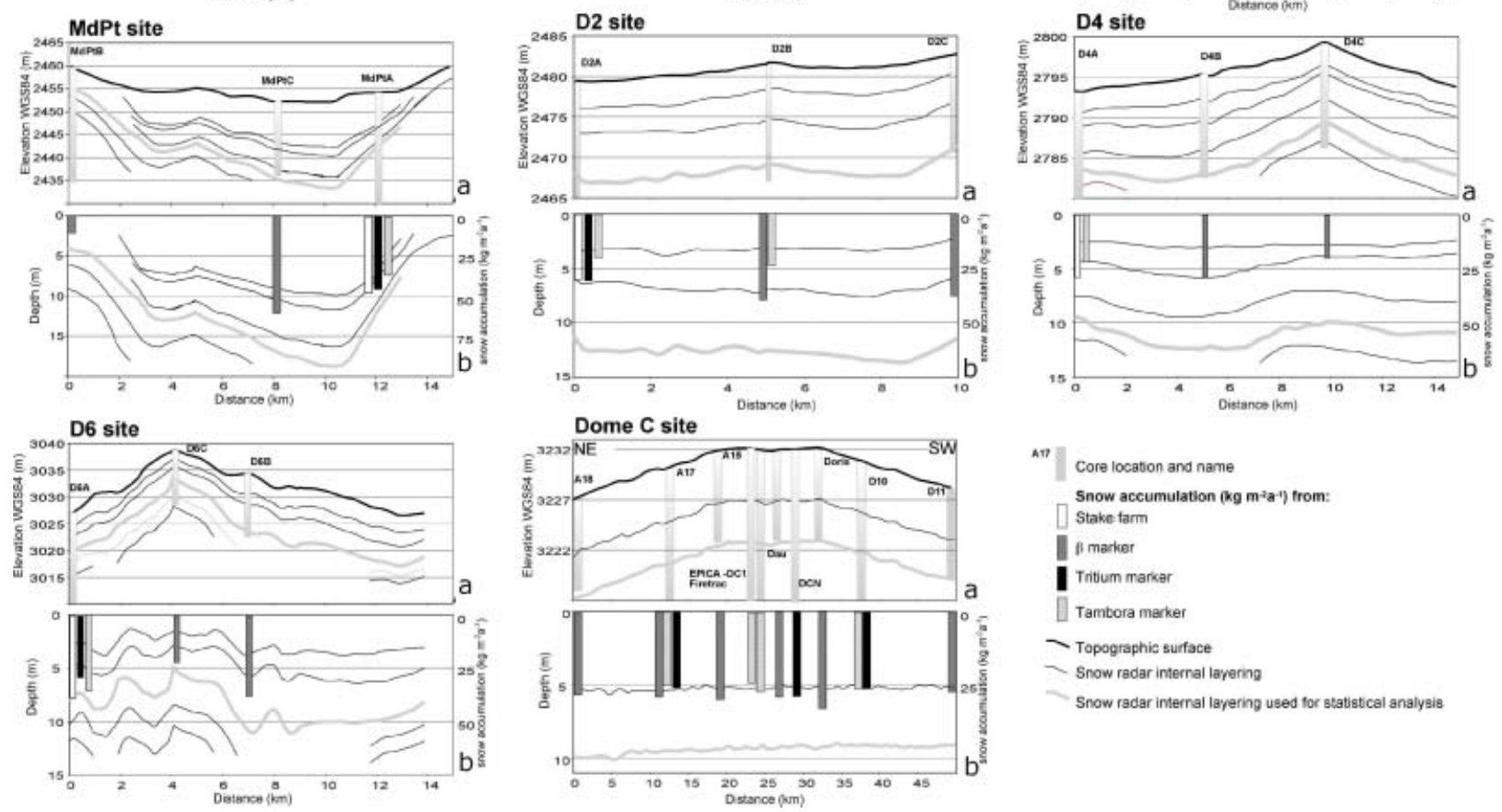

Fig. 2. (a) Core location and elevation of GPR selected horizons and surface profiles; (b) depth profile of GPR selected horizons and snow accumulation from firn cores using different methods.

Table 2. Stake farm results and surface morphology conditions at main core sites. The height of the stakes was measured at middle point (MdPt) in 1998, 1999, 2000, 2001 and 2002, at DC in 1996, 1999, at others sites (31Dpt, D2, D4, D6) in 1998, 2000 and 2002 , at M2 in 1998 and 2002, and at GPS2 in 1993, 1996, 1998 and 2000

\begin{tabular}{|c|c|c|c|c|c|c|c|c|c|}
\hline \multirow[t]{2}{*}{ Site } & $\begin{array}{l}\text { Average snow } \\
\text { accumulation, } \\
\text { 1998-2000 }\end{array}$ & $\begin{array}{l}\text { Std. dev., } \\
\text { 1998-2000 }\end{array}$ & $\begin{array}{l}\text { Number of } \\
\text { stakes without } \\
\text { accumulation } \\
\text { or with } \\
\text { ablation, } \\
\text { 1998-2000 }\end{array}$ & $\begin{array}{l}\text { Average snow } \\
\text { accumulation }\end{array}$ & $\begin{array}{l}\text { Std. dev. } \\
\text { 1998-2002 }\end{array}$ & $\begin{array}{l}\text { Number of } \\
\text { stakes without } \\
\text { accumulation } \\
\text { or with } \\
\text { ablation, } \\
\text { 1998-2002 }\end{array}$ & $\begin{array}{l}\text { Surface } \\
\text { morphology }\end{array}$ & $\begin{array}{l}\text { Sastrugi } \\
\text { average } \\
\text { height }\end{array}$ & $\begin{array}{l}\text { Sastrugi } \\
\text { maximum } \\
\text { height }\end{array}$ \\
\hline & $\mathrm{kg} \mathrm{m}^{-2} \mathrm{a}^{-1}$ & $\%$ & $\%$ & $\mathrm{~kg} \mathrm{~m}^{-2} \mathrm{a}^{-1}$ & $\%$ & $\%$ & & $\mathrm{~cm}$ & $\mathrm{~cm}$ \\
\hline 31Dpt & 105.0 & 22 & 0 & 98.4 & 13 & 0 & Sastrugi & 5 & 10 \\
\hline M2 & - & - & - & 8.5 & 144 & 40 & $\begin{array}{l}\text { Wind-crust } \\
\text { sastrugi }\end{array}$ & 15 & 30 \\
\hline MdPt & 47.4 & 65 & 11 & 46.7 & 40 & 3 & Sastrugi & 30 & 70 \\
\hline D2 & 31.8 & 99 & 19 & 30.4 & 67 & 14 & $\begin{array}{l}\text { Wind-crust } \\
\text { sastrugi }\end{array}$ & 10 & 70 \\
\hline D4 & 38.7 & 48 & 6 & 29.3 & 36 & 0 & $\begin{array}{l}\text { Deposition } \\
\text { form }\end{array}$ & 20 & 40 \\
\hline D6 & 38.0 & 72 & 9 & 39.3 & 78 & 9 & $\begin{array}{l}\text { Deposition } \\
\text { form and } \\
\text { sastrugi }\end{array}$ & 30 & 150 \\
\hline $\begin{array}{l}\text { Dome C } \\
\text { 1996-99 }\end{array}$ & - & - & - & 39.0 & 36 & 0 & $\begin{array}{l}\text { Deposition } \\
\text { form }\end{array}$ & 10 & 30 \\
\hline
\end{tabular}




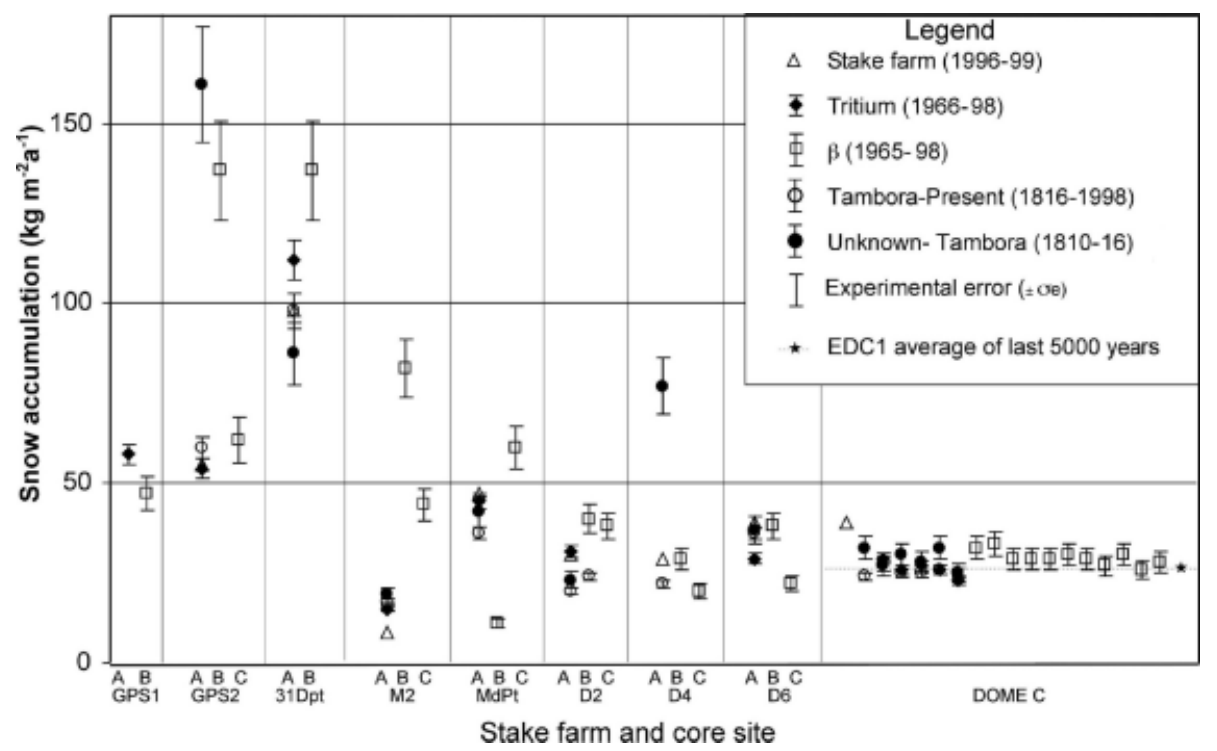

Fig. 3. Snow accumulation rates at core sites using stake farms and different stratigraphic markers.

$100 \mathrm{~m}$ apart forming a cross with an area of $4 \mathrm{~km}^{2}$ (Table 1 ). At DC, a total of 37 stakes were geometrically positioned at a radius of 3, 6, 12 and $25 \mathrm{~km}$ from the centre of DC. Stake heights were measured between 1996 and 2002 (Table 2). The snow accumulation at the stakes was multiplied by the snow density measured in a pit up to $2.5 \mathrm{~m}$ deep to obtain water equivalent values. At DC an average snow accumulation value of $340 \mathrm{~mm}$ of snow $\left(39 \mathrm{~kg} \mathrm{~m}^{-2} \mathrm{a}^{-1}\right)$, with a standard deviation of $125 \mathrm{~mm}\left(14 \mathrm{~kg} \mathrm{~m}^{-2} \mathrm{a}^{-1}\right)$, was measured during the 1996-99 period at the stakes. The absolute elevations of the stakes (measured by GPS) change uniformly, with an average value of $0.9 \mathrm{~cm}$ and standard deviation of $0.9 \mathrm{~cm}$ during the 1996-99 period (Vittuari and others, 2004). The uniform decrease in elevation $(0.9 \pm 0.9 \mathrm{~cm})$ with respect to the snow accumulation value $(340 \mathrm{~mm})$ indicates that the stakes are anchored to the stake bottom. Although snow compaction was not taken into account when calculating snow accumulation, it has often been found to be negligible for accumulation estimation at low-accumulation sites (Lorius, 1983). Snow accumulation variability at stake farms is investigated to determine how representative the results interpreted from a single core might be (Palais and others, 1982).

The integration of GPS and GPR data yields the ellipsoidal height of both the topographic surface and firn stratigraphy (Table 1; Fig. 2). GPS and GPR surveys and subsequent analyses are described elsewhere (Urbini and others, 2001; Frezzotti and others, 2002a). Data acquisition was performed with a Geophysical Survey Systems Inc. Sir10B unit equipped with one monostatic antenna with a central frequency of $400 \mathrm{MHz}$. Principal acquisition parameters were $150 \mathrm{~ns}$ for the vertical investigation range $(15-20 \mathrm{~m})$ and $1-5$ scan s$^{-1}$ for the acquisition rate, i.e. about one scan every 2-3 $\mathrm{m}$ (with the acquisition rate at $1 \mathrm{scan} \mathrm{s}^{-1}$ ) and $0.4-$ $0.7 \mathrm{~m}$ (with the acquisition rate at $5 \mathrm{scan} \mathrm{s}^{-1}$ ). To determine travel times of electromagnetic waves, the depth-density/ depth-speed relation for the snowpack was established using the density profile of three firn cores and one pit in each triangular area along the traverse, and using 17 firn cores and one pit at DC. Density data for each site were fitted with second-order polynomial functions, yielding a correlation coefficient of $R^{2}>0.9$. To facilitate comparison between firn cores and GPR records, the eight calculated polynomial functions were used to convert firn depths in the seven triangular areas and at DC into water equivalent depths. The depth of the GPR layer was then converted into snow accumulation (GPR_SA) using the depth/age ratio from the 'main' core tritium snow accumulation. Snow accumulation data derived from core records are in good agreement with data derived from GPR_SA (Table 1). In line with other authors (e.g. Richardson and others, 1997; Vaughan and others, 1999; Spikes and others, 2004), we assume that the layers producing strong radar reflections are isochronal.

Differences in snow accumulation between the main cores and the secondary cores (Figs 2 and 3) are equally reflected in tritium $/ \beta$ marker and GPR data (Table 1$)$. The two methods yield different results because they sample different areas: the core diameter is $7-10 \mathrm{~cm}$, while GPR works at the metre scale. Major differences between the results of the two methods (core and GPR) are found in regions of large spatial variability in accumulation (GPS2, $\mathrm{M} 2$ and MdPt sites). The maximum difference between core and GPR $(20 \%)$, and the highest GPR relative standard deviation (47\%) are found at site GPS2. GPS2A and GPS2C cores were drilled a few tens of metres apart and show a $13 \%$ difference in accumulation for the tritium $/ \beta$ marker horizons (Figs 1-3; Table 1). In contrast, the lowest standard deviation was obtained at DC $(3 \%)$.

Topographic characterization of each site (elevation, slope, etc.) was performed using the European Remotesensing Satellite-1 (ERS-1) radar altimeter digital terrain model, with a grid spacing of $1 \mathrm{~km}$, provided by Rémy and others (1999). A $3 \times 3$ pixel window was used to calculate the slope of each grid using the digital terrain model.

\section{RESULTS}

\section{Core sites morphological and climatological characteristics}

Meteorological data and a continental-scale simulation of the surface wind field (Parish and Bromwich, 1991) show 


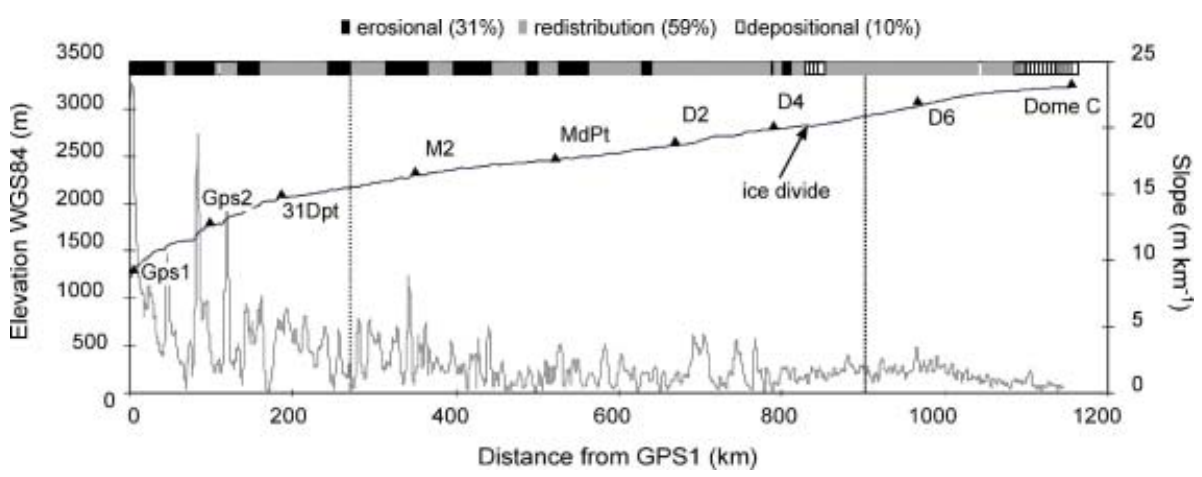

Fig. 4. Surface elevation (solid line), terrain slope (grey line) and micro-relief distribution along TNB-DC traverse. Core sites are indicated with triangles.

that the area between TNB and DC is characterized by a katabatic wind flow, with speeds ranging from $<6$ to $>18 \mathrm{~m} \mathrm{~s}^{-1}$ (Table 1).

The topographic profile of the traverse indicates three sectors (Fig. 4): an area extending about $250 \mathrm{~km}$ from GPS1 (slope area), characterized by a large slope of up to $25 \mathrm{~m} \mathrm{~km}^{-1}$, a second area (plateau area) up to about $900 \mathrm{~km}$, with a slope of up to $4.5 \mathrm{~m} \mathrm{~km}^{-1}$, and the dome area in the last $250 \mathrm{~km}$, with a slope of $<2 \mathrm{~m} \mathrm{~km}^{-1}$. The slope profile shows very high variability in the first and second areas, and a nearly constant slope in the third area (Frezzotti and Flora, 2002). The surface morphology in the slope and plateau areas is very irregular and can be linked mainly to flow over undulations in the bedrock morphology and secondarily to environmental conditions (wind and accumulation). In the dome area, surface variability is derived mainly from environmental conditions and secondarily from the bedrock morphology. Only the megadunes in the dome area, close to D6 (Fig. 1), show a pattern of regular oscillation of the surface (Fahnestock and others, 2000). Megadune formation can be explained by a cyclic variation of the erosion and redistribution process of snow along a slope by an atmospheric wave, with the atmospheric wavelength the same order of magnitude as the megadune (Frezzotti and others, 2002a).

Analysis of the morphological conditions of the region shows that (Figs 1 and 2; Table 1):

GPS2, M2 and MdPt are characterized by relatively complex morphologies with 'abrupt' changes in slope and wind direction;

31Dpt area contains relatively 'steep' slopes $\left(>4 \mathrm{~m} \mathrm{~km}^{-1}\right)$, but the wind direction is close to the direction of elevation contours, and the slope in the wind direction is therefore very low;

D2 and D4 present low slopes, with a 50-65 angle between the wind direction and the direction of the general surface slope; the D6 core site is located just a few kilometres leeward of the megadune field (Frezzotti and others, 2002a);

DC has the lowest slope, and the major axis of the dome is aligned in the direction of the prevailing wind.

Micro-relief along the TNB-DC traverse consists (Fig. 4) of $31 \%$ erosional features (wind crust), 59\% redistribution features (sastrugi) and only 10\% depositional features (Frezzotti and others, 2002b). The micro-relief characteristics of core sites (5 km apart), where topography is 'relatively complex' (GPS2, M2 and MdPt), are very different (Figs 1 and 2; Table 1). The D2 and 31Dpt areas are characterized by the alternation of sastrugi fields with sporadic longitudinal dunes (10-20 m long, a few metres wide and up to $1 \mathrm{~m}$ high), and by seasonal wind crust with sporadic sastrugi. Depositional micro-relief occurs extensively only in the D4 area, a point close to the David Glacier ice divide, and near DC (Frezzotti and others, 2002b). The GPS2A, $\mathrm{M} 2 \mathrm{~A}$ and MdPtC core sites are characterized by the extensive presence of wind crust, consisting of a single snow-grain layer cemented by thin $(0.1-2 \mathrm{~mm})$ films of ice, with cracks (up to $2 \mathrm{~cm}$ wide) and polygonal pattern. Wind crusts form on the surface due to the kinetic heating of saltating snow under constant katabatic wind flow (Goodwin, 1990) and the condensation-sublimation process on both sides of the crust (Fujii and Kusunoki, 1982). Larger grain-sizes are found at the GPS2A, M2A and MdPtC sites. At other sites smaller grains are found in sastrugi or depositional areas (31DptA, MdPtA, D2A, D4A, D6A and DC). Sites MdPtC and MdPtA are only $5 \mathrm{~km}$ apart (Fig. 1) but show quite different grain-size profiles, in terms of both mean values and variability (Gay and others, 2002). The MdPtA site contained sastrugi up to $20 \mathrm{~cm}$ high, but no permanent wind crust. The large difference in grain-size at the two sites is due to different local-scale snow accumulation processes.

\section{Local spatial variability of snow accumulation}

The accumulation/ablation pattern derived from the stakefarm measurements shows large standard deviations (Table 2), and largely reflects snow surface roughness (sastrugi) and/or an interruption in accumulation (wind crust) at the sites. This variability or 'noise' is important, and limits the degree to which a single annual snow accumulation value may be temporally representative (Fisher and others, 1985). Analysis of the MdPt stake-farm data surveyed each year from 1998 to 2002 reveals localscale spatial variability, suggesting that the annual local noise (metre scale) in snow accumulation could be between $\sim 2$ and 4 times the mean snow accumulation, with accumulation $\leq 0$ for $32 \%$ of annual-scale observations.

It appears that stake measurements and surface morphology are strongly related at all sites. The lowest standard deviation values are present when the slope along prevalent wind direction (SPWD) is low (31Dpt, D4 

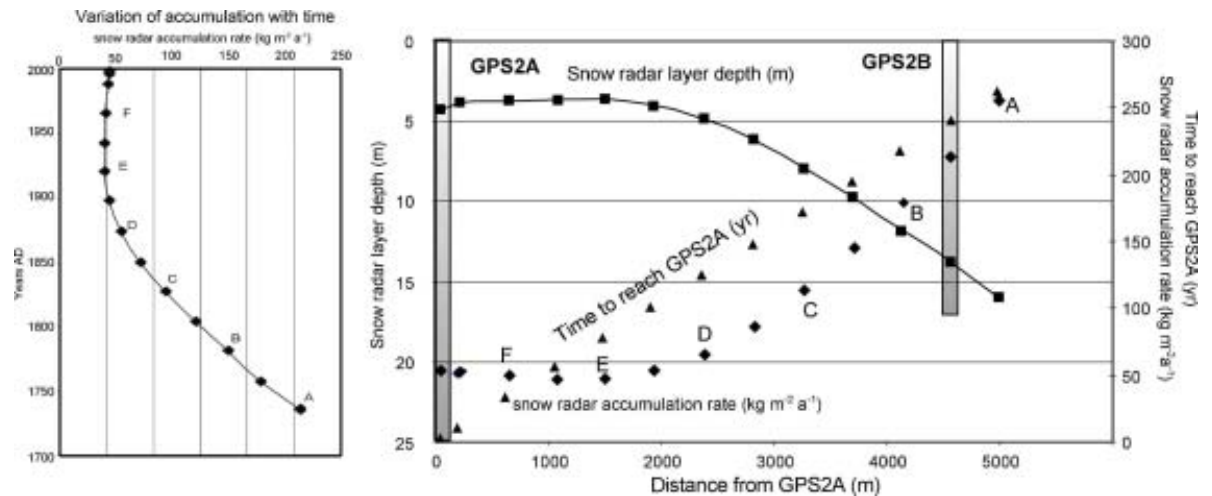

Fig. 5. 'Simulation' of snow accumulation rate at GPS2A core using snow-radar, ice velocity and core analyses.

and DC). In contrast, site M2, with a high SPWD variability, shows the lowest accumulation value and the highest standard deviation of $144 \%$, with accumulation $\leq 0$ for a 5 year period in $40 \%$ of cases. We generally obtained the same mean value for a 5 year period but a much lower variability between individual points, thus concurring with the observation at the old Dome C (Palais and others, 1982; Petit and others, 1982). Ekaykin and others (2004) pointed out that at Vostok the period of smoothing necessary to suppress the noise, due to micro-relief, was estimated to be 7 years both for snow accumulation and for $\delta \mathrm{D}$ time series. This is because the mean surface roughness tends to be conserved, implying a preferential deposition of snow at low-level points and erosion of sastrugi (Gow, 1965; Petit and others, 1982; Alley, 1988).

\section{Temporal variability in snow accumulation and ice-core interpretations}

The analysis of spatial variability in snow accumulation at different sites along the traverse also shows an extremely high variability of snow accumulation at the local $(\mathrm{km})$ scale, particularly for sites with a standard deviation in snow accumulation greater than $10 \%$ of the mean value (GPS2, M2, MdPt, D6). Tables 1 and 3 show that snow accumulation variability reaches an order of magnitude in a single core (e.g. M2A and GPS2A). Table 1 and Figure 3 show that snow accumulation variability changes with depth (difference between stakes and Tambora accumulation) and reaches an order of magnitude in a single core. The very high spatial variability in snow accumulation may influence the interpretation of firn-/ice-core records. This is clear when looking at the GPS2A and GPS2B data. GPS2A and GPS2B cores are located along a flowline and the distance between the two core sites is about $5 \mathrm{~km}$ (Fig. 1). Snow deposited at GPS2B reaches GPS2A after about 250 years (ice velocity $19 \mathrm{~m} \mathrm{a}^{-1}$; Vittuari and others, 2004). GPR and core analyses reveal (Figs 2 and 3; Table 1) that snow accumulation at site GPS2B is three times higher $\left(137 \mathrm{~kg} \mathrm{~m}^{-2} \mathrm{a}^{-1}\right)$ than at site GPS2A $\left(54 \mathrm{~kg} \mathrm{~m}^{-2} \mathrm{a}^{-1}\right)$. A simple one dimensional (1-D) model can be used to calculate past accumulation rates at GPS2A using the snow accumulation rate derived from GPR, the depth-age function of firn cores and ice velocity. The 1-D model allows evaluation of the submergence velocity (or burial rate) of the surface and 'simulation' of the snow accumulation rate at core GPS2A (Fig. 5). We did not take into account layer thinning due to vertical strain, because the ratio of the investigated layer depth $(20 \mathrm{~m})$ to the entire ice thickness ( $>3000 \mathrm{~m}$; Testut and others, 2000 ) is $<1 \%$ and is therefore negligible. Other reasons to neglect strain thinning include the very small strain rates that are present in this part of the ice sheet, and the short duration ( 250 years) of the records over which to accumulate this strain. The analysis of snow accumulation (stakes, tritium, Tambora, unknown) reveals an increase in accumulation with depth (1965-present: $54 \mathrm{~kg} \mathrm{~m}^{-2} \mathrm{a}^{-1}$; unknownTambora: $\left.161 \mathrm{~kg} \mathrm{~m}^{-2} \mathrm{a}^{-1}\right)$; 'simulation' and present snow accumulation values at GPS2B are very similar, showing that the core variability is due to a spatial variability and not a temporal variability.

Table 3. Spatial variability in surface mass balance from GPR calibrated using accumulation at the main core

\begin{tabular}{|c|c|c|c|c|c|c|c|}
\hline \multirow{3}{*}{ Site } & \multirow{3}{*}{$\begin{array}{l}\text { Average } \\
\mathrm{kg} \mathrm{m}^{-2} \mathrm{a}^{-1}\end{array}$} & \multirow{3}{*}{ Std. dev. } & \multicolumn{4}{|c|}{ Spatial variability of surface mass balance from GPR* } & \multirow{3}{*}{$\begin{array}{l}\text { Max - Min } \\
\%\end{array}$} \\
\hline & & & Std. dev. & Min & Max & Max - Min & \\
\hline & & & $\%$ & $\mathrm{~kg} \mathrm{~m}^{-2} \mathrm{a}^{-1}$ & $\mathrm{~kg} \mathrm{~m}^{-2} \mathrm{a}^{-1}$ & $\mathrm{~kg} \mathrm{~m}^{-2} \mathrm{a}^{-1}$ & \\
\hline GPS2 & 93 & 44 & 47 & 45 & 201 & 156 & 78 \\
\hline 31Dpt & 108 & 11 & 10 & 86 & 128 & 42 & 33 \\
\hline M2 & 76 & 26 & 34 & 17 & 115 & 98 & 85 \\
\hline $\mathrm{MdPt}$ & 38 & 14 & 37 & 10 & 59 & 48 & 82 \\
\hline D2 & 43 & 2 & 5 & 37 & 46 & 9 & 20 \\
\hline D4 & 26 & 2.5 & 9 & 22 & 30 & 8 & 26 \\
\hline D6 & 29 & 7 & 24 & 17 & 41 & 24 & 58 \\
\hline Dome $C^{*}$ & 26 & 0.8 & 3 & 25 & 28 & 3 & 12 \\
\hline
\end{tabular}

\footnotetext{
* Spatial variability has been evaluated along $15 \mathrm{~km}$ profile for each site along the traverse and along a $100 \mathrm{~km}$ profile at Dome C.
} 

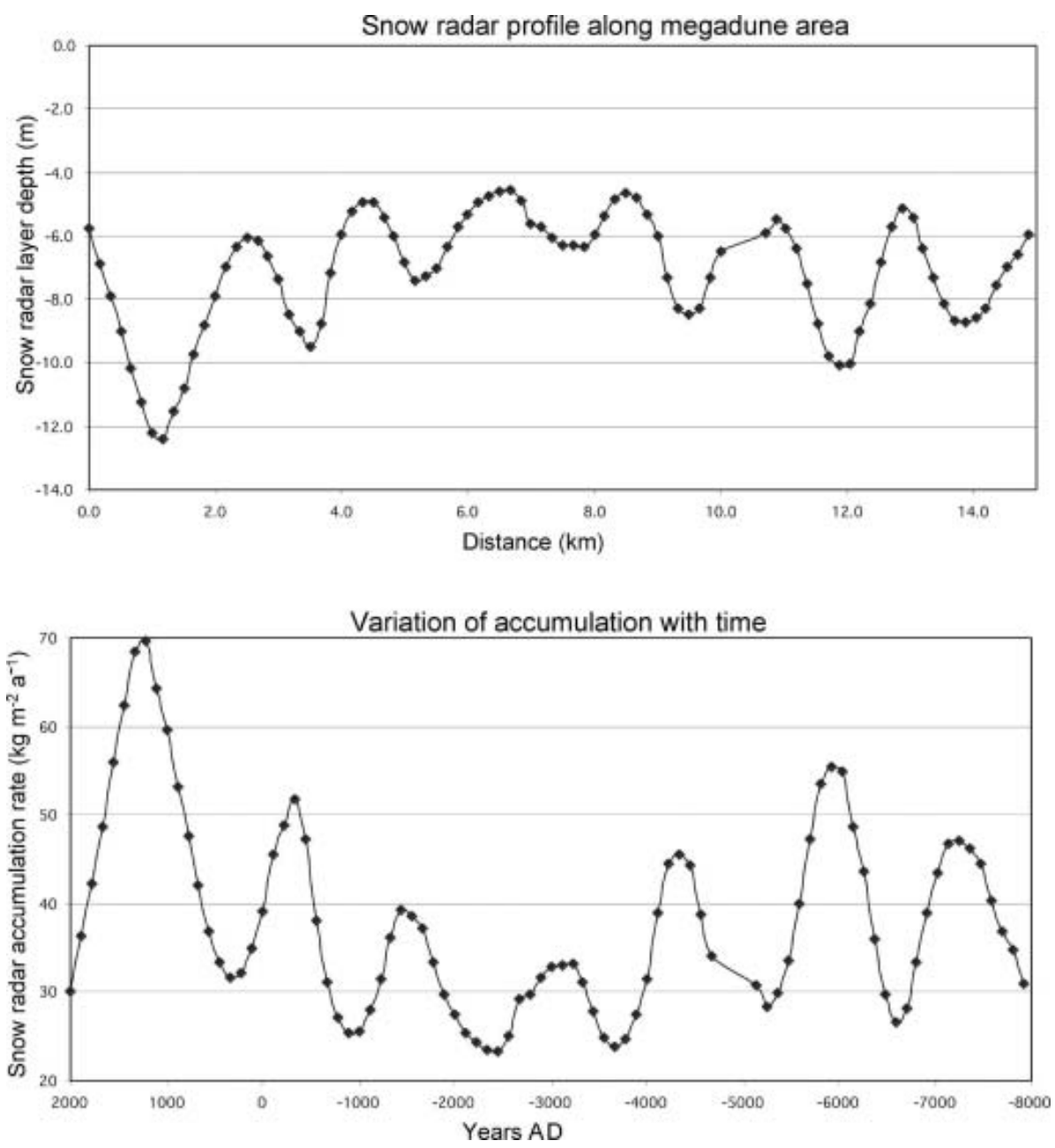

Fig. 6. 'Simulation' of snow accumulation rate at D6A core using snow-radar and core analyses.

Core site D6 is downstream of a field of megadunes with wavelengths of about $2-3 \mathrm{~km}$ and amplitudes of $2-4 \mathrm{~m}$ (Frezzotti and others, 2002a). Accumulation in this area is about $30 \mathrm{~kg} \mathrm{~m}^{-2} \mathrm{a}^{-1}$, which is too low to allow identification of seasonal signals in the isotope-chemistry stratigraphy of the firn core. A GPR profile $45 \mathrm{~km}$ west of D6 follows the iceflow direction in the megadune area and reveals the presence of buried megadunes. As for GPS2, the 1-D model (GPR and ice velocity: $1.5 \mathrm{~m} \mathrm{a}^{-1}$; Vittuari and others, 2004) can be used to estimate the snow accumulation rate in the megadune area (Fig. 6). The 'simulated' accumulation rate shows a periodic variation of about 1500 years, with a standard deviation in the snow accumulation rate of about $28 \%$.

The sites with $<10 \%$ standard deviation (31Dpt, D2 and D4) show an increase in accumulation (14-55\%) between Tambora-present (1816-1998) and tritium/ $\beta$-present (196698; Table 1). Also DC shows a clear increase in accumulation from the Tambora marker (average $25.3 \pm 1 \mathrm{~kg} \mathrm{~m}^{-2} \mathrm{a}^{-1}$ ) to tritium $\beta$ (average $28.3 \pm 2.4 \mathrm{~kg} \mathrm{~m}^{-2} \mathrm{a}^{-1}$ ) to the stake farm (average $39 \mathrm{~kg} \mathrm{~m}^{-2} \mathrm{a}^{-1}$ with a standard deviation of $14 \mathrm{~kg} \mathrm{~m}^{-2} \mathrm{a}^{-1}$ ). With respect to the Tambora marker, stakefarm values show a $30 \%$ increase in accumulation during the $1996-99$ period. The tritium $/ \beta$ marker also records about a $10 \%$ increase. Based on the age-depth scale from the EPICA (European Project for Ice Coring in Antarctica) DC1 core, the accumulation average over the last 5000 years is $26.6 \mathrm{~kg} \mathrm{~m}^{-2} \mathrm{a}^{-1}$, with a standard deviation of $1.0 \mathrm{~kg} \mathrm{~m}^{-2} \mathrm{a}^{-1}$ (Schwander and others, 2001).

\section{DISCUSSION}

The reconstruction of past climates based on ice-core data from areas with high accumulation spatial variability can be distorted. Processes induced by snow accumulation spatial variability that occur mainly in porous snow (depth hoar) under wind crust, such as:

mass exchange by diffusion (isotope),

gaseous re-emission $\left(\mathrm{NO}_{3}{ }^{-}, \mathrm{nssCl}^{-}\right.$and $\left.\mathrm{MSA}\right)$,

densification, and metamorphic processes (highly recrystallized firn, permeability, grain-size, snow porosity, close-off, total air content, etc.),

may be the source of ice record misinterpretation (e.g. Alley, 1988; Wolff, 1996; Mulvaney and others, 1998; Delmotte and others, 1999; Wagnon and others, 1999; Traversi and others, 2000; Proposito and others, 2002).

It is important to consider aeolian processes when selecting optimum sites for firn/ice coring because slope variations of even a few metres per kilometre have a significant impact on winds. As a consequence, a lack of information on local conditions (GPR) can lead to the incorrect definition of climatic conditions based on the interpretation of core stratigraphy alone. Based on our observations, the sites with high standard deviation of spatial variability in snow accumulation (GPS2, M2, MdPt and D6) are not useful in providing information on temporal 
variations in snow accumulation, because interpretation is very difficult or impossible when the snow originates from different snow accumulation conditions.

At Vostok station, Antarctica, significant oscillations of snow accumulation and snow isotope composition up to 20 years and possibly $\sim 10^{2}$ years have been observed and are interpreted in terms of drift of snow accumulation waves of various scales on the surface of the ice sheet (Ekaykin and others, 2002). Those authors have observed similar periodicity in the $\delta \mathrm{D}$ profile of the Vostok ice core at different depths.

The Vostok core may contain sections of ice that were once megadunes, and accumulated snow may have also been affected by spatial variability. Based on present ice flow at the Vostok ice core (Bell and others, 2002), the slope change from the flat surface (due to the subglacial lake) to the slope coming from Ridge B occurred at the end of the Last Glacial Maximum (about 20000 years ago). Variations in snow accumulation at that time could then be due to the change in slope and increase in wind-driven sublimation. Siegert (2003) pointed out that upstream of Vostok lake there is a significant difference between the accumulation rate during the glacial period and the more recent period. Udisti and others (2004) used stratigraphic correlation between the EPICA Dome C and Vostok ice cores to show the relative variations of snow accumulation over the past $45 \mathrm{kyr}$. The correlation shows higher variability between glacial and Holocene conditions at DC than at Vostok. They interpret the difference to be due to regional changes in atmospheric circulation with either a negative anomaly in DC or a positive accumulation anomaly in Vostok, or a combination of both.

The Dome C area was chosen for the EPICA deep-drilling project. Deep drilling recently (January 2003) recovered a $3201 \mathrm{~m}$ ice core that provides a climate record extending more than $750 \mathrm{kyr}$ (EPICA community members, 2004). The drill site is about $1.4 \mathrm{~km}$ east of the present culmination. Our measurements show that the snow accumulation variability is smallest at DC and that over an area of $50 \mathrm{~km}$ in diameter (about $2000 \mathrm{~km}^{2}$ ) the standard deviation in spatial variability $(3 \%)$ and the difference between maximum and minimum values $(12 \%)$ are very small.

An $11 \%$ increase in accumulation was observed at Talos Dome during the 20th century, while from 1966 to the present there has been a $7 \%$ increase with respect to the 800 year average (Stenni and others, 2002). The clear increase in accumulation at DC, as indicated by stakes and tritium $/ \beta$ compared to Tambora, is consistent with that observed at other sites in East Antarctica, suggesting a regional-scale phenomenon. Stenni and others (2002) found agreement between Talos Dome and DC isotopic profiles, which was attributed to similarly distributed storm tracks and sources of moisture. Recent increases in accumulation have been reported at other Antarctic locations. Pourchet and others (1983) observed a 30\% increase in accumulation at 14 Antarctic sites (including Vostok, old Dome C, the South Pole and Ross Ice Shelf) in the period 1960-75 compared to the period 1955-60. This general trend was also observed some years later in the South Pole area, with a $32 \%$ increase between 1960 and 1990 (Mosley-Thompson and others, 1995, 1999). At Vostok station, the comparison between a stack of eight sites (six cores and three deep pits) for Tambora marker and nine sites for $\beta$ marker suggests a slight increase of snow accumulation during the last two centuries (Ekaykin and others, 2004). Stacked records of $\delta \mathrm{D}$ and snow accumulation for the period 1774-1999 show a 50 year cycle. These variations seem to be in phase with the Pacific Decadal Oscillation index, which suggests a teleconnection between central Antarctica and the tropical Pacific (Ekaykin and others, 2004). In Wilkes Land, Morgan and others (1991) observed a decrease in the accumulation rate from 1955 to 1960, with an increase during the subsequent period. Stenni and others (1999) reported no significant accumulation change from a 200 year ice-core record in northern Victoria Land. In Dronning Maud Land (DML), Isaksson and others (1996) observed a decrease in accumulation from 1932 to 1991. Oerter and others (1999) reported a decrease in accumulation in DML during the 19th century followed by an increase during the 20th century, and these trends were linked to temperature variations derived from stable-isotope records. Mosley-Thompson and others (1999) suggest that South Pole's recent accumulation increase may be characteristic of the high East Antarctic plateau.

We observed that the increase in accumulation is mainly evident in the central part of the plateau or at dome sites, where the ablation processes have less impact on snow accumulation.

Mosley-Thompson and others (1995) pointed out that the observed increase is not well understood, but that there are several dominant processes that affect snow precipitation (e.g. variability in the sea-ice extent, changes in moisture source regions, frequency, duration and seasonality of cyclonic storms). Bromwich and others (2004), using atmospheric models (ECT/ERA-15, NCEP2 and DRM) to calculate precipitation over Antarctica from 1979 to 1999 , found an upward trend of $1.3-1.7 \mathrm{~kg} \mathrm{~m}^{-2} \mathrm{a}^{-1}$, which is significant at $95 \%$ confidence level for all three datasets. They pointed out that the precipitation increase is consistent with the positive trend in sea-surface temperatures observed in the mid-latitudes of the Southern Ocean over the latter half of 20th century (Casey and Cornillon, 2001), this region encompassing the source region of Antarctic precipitation (Delaygue and others, 1999). In addition to these effects, wind-driven sublimation processes must be considered as factors affecting the snow accumulation. Wind-driven sublimation processes, controlled by the surface slope in the wind direction, have a huge impact (up to $85 \%$ of snow precipitation) on surface mass-balance and are significant in terms of past, present and future surface mass-balance evaluations (Frezzotti and others, 2004). The analysis of a 20 year (1980-2000) surface-temperature record shows a general cooling of the Antarctic continent, warming of the sea-ice zone, and moderate changes over the ocean (Doran and others, 2002; Kwok and Comiso, 2002; Torinesi and others, 2003). Wind speeds over sloping terrain increase with decreasing temperature; cold temperatures are associated with strong inversions and hence strong gravitational flows (Wendler and others, 1993). Cooler temperatures over East Antarctica and warming in sea-ice areas increase the temperature gradient, and the persistence of katabatic winds and associated wind-driven sublimation. The area with speeds less than $6 \mathrm{~m} \mathrm{~s}^{-1}$ represents about $10 \%$ of the surface in the continental-scale simulation of the surface wind field (Parish and Bromwich, 1991). An increase in snow precipitation coupled with an increase in temperature and/ or wind could increase the surface mass balance only in the inner part of East Antarctica where the wind speed is $<6 \mathrm{~m} \mathrm{~s}^{-1}$, whereas it could lead to a decrease in surface 
mass balance in the windy areas that represent $90 \%$ of the Antarctic surface (Frezzotti and others, 2004).

\section{CONCLUSIONS}

The accumulation/ablation pattern derived from stake-farm measurements, wind crust presence and sastrugi heights, suggests that the local annual noise (metre scale) in snow accumulation can be between $\sim 2$ and 4 times the average annual accumulation, with no accumulation or ablation for a 5 year period in up to $40 \%$ of cases. The lowest standard deviation value is present where the snow accumulation is the highest and/or where the slope along the prevalent wind direction is low. If we compare the stake-farm measurements to the series derived from stratigraphic core analysis, we observe that the number of gaps of one or more years increases with spatial variability and wind scouring.

At many sites stake-farm and ice-core accumulation rates are observed to differ significantly, but isochrones (GPR) correlate well with ice-core derived accumulation.

The spatial variability of snow accumulation at the kilometre scale is one order of magnitude higher than temporal variability (20-30\%) at the multi-decade/secular scale. The reconstruction of past climates based on firn/ice cores drilled in areas with high snow accumulation spatial variability $(>10 \%)$ will be complicated. In megadune areas the distortion of recordings is characterized by a snow accumulation periodicity of about 1500 years. A future intermediate ice core (about $500 \mathrm{~m}$ deep) downwind of the megadune area could provide information about the periodicity (about seven oscillations) induced by megadunes in deep ice cores. The length of periodic variations due to mesoscale relief and/or megadunes depends on ice velocity and snow accumulation, and can therefore vary in space and time. Nevertheless the length of these periodic variations should be consistent with the use of ice-core accumulation records to study temporal changes in snow accumulation (decade scale). Domes are the preferred sites for studying the temporal variability of climate using firn/ice cores, because interpretation is easier when all the snow originates from the same point on the surface. Ice/firn cores require surveys (snow radar, GPS, etc.) to characterize the site and its geographical/environmental representativeness.

Our results show that wind-driven sublimation has a strong impact on snow accumulation.

Stake measurements and firn cores at Dome C confirm an approximate $30 \%$ increase in accumulation over the last two centuries, with respect to the average over the last 5000 years. An increase in accumulation was also observed at other sites where the slope along the prevalent wind direction is small (31Dpt, D2 and D4). Ice-core records from relatively 'high'-slope $\left(>2 \mathrm{~m} \mathrm{~km}^{-1}\right)$ areas should be avoided because wind processes are very likely to affect them; shortterm changes in snow precipitation should thus be studied only in dome areas or at sites undisturbed by winds. Winddriven ablation greatly affects snow accumulation, and one of the largest sources of uncertainty regarding present and future surface mass-balance calculations is the role of winddriven sublimation. An increase in snow precipitation coupled with an increase in temperature and/or wind could increase the surface mass balance only in the inner part of East Antarctica where the wind speed is $<6 \mathrm{~m} \mathrm{~s}^{-1}$, whereas it could lead to a decrease in surface mass balance in the windy areas that represent $90 \%$ of the Antarctic surface.

\section{ACKNOWLEDGEMENTS}

Research was carried out in the framework of the Project on Glaciology of the Programma Nazionale di Ricerche in Antartide-Ministero Istruzione Universitá, Ricerca (PNRAMIUR) and was financially supported by PNRA through a cooperation agreement with ENEA Roma. This work is a contribution by the Italian branch of the ITASE project and is also supported by the French Polar Institute (IPEV). It is an associate program to the 'European Project for Ice Coring in Antarctica' (EPICA), a joint European Science Foundation/ European Commission scientific program. The authors wish to thank all members of the traverse team, the participants in PNRA 1998/99 who assisted at the Zucchelli station at Terra Nova Bay and Concordia Station and everyone who helped prepare the traverse. Thanks are due to V. Masson-Delmotte, E. Isaksson, M. Fahnestock and G. Hamilton whose comments and editing helped to improve the manuscript.

\section{REFERENCES}

Alley, R.B. 1988. Concerning the deposition and diagenesis of strata in polar firn. J. Glaciol., 34(118), 283-290.

Becagli, S. and 6 others. 2003. Variability of snow depositions along the 1998/99 ITASE traverse. Terra Antartica Reports, 8, 43-48.

Bell, R.E., M. Studinger, A.A. Tikku, G.K.C. Clarke, M.M. Gutner and C. Meertens. 2002. Origin and fate of Lake Vostok water frozen to the base of the East Antarctic ice sheet. Nature, 416(6878), 307-310.

Black, H.P. and W. Budd. 1964. Accumulation in the region of Wilkes, Wilkes Land, Antarctica. J. Glaciol., 5(37), 3-15.

Bromwich, D.H. and C.J. Weaver. 1983. Latitudinal displacement from main moisture source controls $\delta^{18} \mathrm{O}$ of snow in coastal Antarctica. Nature, 301(5896), 145-147.

Bromwich, D.H., Z. Guo, L. Bai and Q. Chen. 2004. Modelled Antarctic precipitation. Part I: spatial and temporal variability. J. Climate, 17(3), 427-447.

Capra, A., R. Cefalo, S. Gandolfi, G. Manzoni, I.E. Tabacco and L. Vittuari. 2000. Surface topography of Dome Concordia (Antarctica) from kinematic interferential GPS and bedrock topography. Ann. Glaciol., 30, 42-46.

Casey, K.S. and P. Cornillon. 2001. Global and regional sea surface temperature trends. J. Climate, 14(18), 3801-3818.

Cole-Dai, J., E. Mosley-Thompson and L.G. Thompson. 1997. Annually resolved Southern Hemisphere volcanic history from two Antarctic ice cores. J. Geophys. Res., 102(D14), 16,761$16,771$.

Dai, J., E. Mosley-Thompson and L.G. Thompson. 1991. Ice core evidence for an explosive tropical volcanic eruption 6 years preceding Tambora. J. Geophys. Res., 96(D9), 17,361-17,366.

Delaygue, G., V. Masson and J. Jouzel. 1999. Climatic stability of the geographic origin of Antarctic precipitation simulated by an atmospheric general circulation model. Ann. Glaciol., 29, 45-48.

Delmotte, M., D. Raynaud, V. Morgan and J. Jouzel. 1999. Climatic and glaciological information inferred from air-content measurements of a Law Dome (East Antarctica) ice core. J. Glaciol., 45(150), 255-263.

Doran, P.T. and 12 others. 2002. Antarctic climate cooling and terrestrial ecosystem response. Nature, 415(6871), 517-520. (doi:10.1038/nature710.)

Ekaykin, A.A., V.Ya. Lipenkov, N.I. Barkov, J.R. Petit and V. MassonDelmotte. 2002. Spatial and temporal variability in isotope composition of recent snow in the vicinity of Vostok station, Antarctica: implications for ice-core record interpretation. Ann. Glaciol., 35, 181-186. 
Ekaykin, A.A., V.Ya. Lipenkov, I.N. Kuz'mina, J.R. Petit, V. MassonDelmotte and S.J. Johnsen. 2004. The changes in isotope composition and accumulation of snow at Vostok Station over the past 200 years. Ann. Glaciol., 39, 569-575.

EPICA community members. 2004. Eight glacial cycles from an Antarctic ice core. Nature, 429(6992), 623-628. (doi:10.1038/ nature02599.)

Fahnestock, M.A., T.A. Scambos, C.A. Shuman, R.J. Arthern, D.P. Winebrenner and R. Kwok. 2000. Snow megadune fields on the East Antarctic Plateau: extreme atmosphere-ice interaction. Geophys. Res. Lett., 27(22), 3719-3722.

Fisher, D.A., N. Reeh and H.B. Clausen. 1985. Stratigraphic noise in the time series derived from ice cores. Ann. Glaciol., 7, 76-83.

Frezzotti, M. and O. Flora. 2002. Ice dynamic features and climatic surface parameters in East Antarctica from Terra Nova Bay to Talos Dome and Dome C: ITASE Italian traverses. Terra Antartica, 9(1), 47-54.

Frezzotti, M., S. Gandolfi, F. La Marca and S. Urbini. 2002a. Snow dunes and glazed surfaces in Antarctica: new field and remotesensing data. Ann. Glaciol., 34, 81-88.

Frezzotti, M., S. Gandolfi and S. Urbini. 2002b. Snow megadunes in Antarctica: sedimentary structure and genesis. J. Geophys. Res., 107(D18), 4344. (doi: 10.1029/2001JD000673.)

Frezzotti, M. and 12 others. 2004. New estimations of precipitation and surface sublimation in East Antarctica from snow accumulation measurements. Climate Dyn. (doi: 10.1007/s00382-0040462-5.)

Fujii, Y. and K. Kusunoki. 1982. The role of sublimation and condensation in the formation of ice sheet surface at Mizuho Station, Antarctica. J. Geophys. Res., 87(C6), 4293-4300.

Gay, M., M. Fily, C. Genthon, M. Frezzotti, H. Oerter and J.-G. Winther. 2002. Snow grain-size measurements in Antarctica. J. Glaciol., 48(163), 527-535.

Goodwin, I.D. 1990. Snow accumulation and surface topography in the katabatic zone of eastern Wilkes Land, Antarctica. Antarct. Sci., 2(3), 235-242.

Gow, A.J. 1965. On the accumulation and seasonal stratification of snow at the South Pole. J. Glaciol., 5(40), 467-477.

Gragnani, R., C. Smiraglia, B. Stenni and S. Torcini. 1998. Chemical and isotopic profiles from snow pits and shallow firn cores on Campbell Glacier, northern Victoria Land, Antarctica. Ann. Glaciol., 27, 679-684.

Isaksson, E., W. Karlén, N. Gundestrup, P. Mayewski, S. Whitlow and M. Twickler. 1996. A century of accumulation and temperature changes in Dronning Maud Land, Antarctica. J. Geophys. Res., 101(D3), 7085-7094.

Jouzel, J., L. Merlivat, M. Pourchet and C. Lorius. 1979. A continuous record of artificial tritium fallout at the South Pole (1954-1978). Earth Planet. Sci. Lett., 45(1), 188-200.

Jouzel, J., L. Merlivat, J.R. Petit and C. Lorius. 1983. Climatic information over the last century deduced from a detailed isotopic record in the South Pole snow. J. Geophys. Res., 88(C4), 2693-2703.

Kwok, R. and J.C. Comiso. 2002. Spatial patterns of variability in Antarctic surface temperature: connections to the Southern Hemisphere annual mode and the Southern Oscillation. Geophys. Res. Lett., 29(14). (doi: 10.1029/2002GL015415.)

Legrand, M.R. and R.J. Delmas. 1987. A 220-year continuous record of volcanic $\mathrm{H}_{2} \mathrm{SO}_{4}$ in the Antarctic ice sheet. Nature, 327(6124), 671-676.

Liston, G.E., J.-G. Winther, O. Bruland, H. Elvehøy, K. Sand and L. Karlöf. 2000. Snow and blue-ice distribution patterns on the coastal Antarctic ice sheet. Antarct. Sci., 12(1), 69-79.

Lorius, C. 1983. Accumulation rate measurements on cold polar glaciers. In Robin, G.de Q., ed. The climatic record in polar ice sheets. Cambridge, Cambridge University Press, 65-70.

Mayewski, P.A. and I. Goodwin. 1999. Antarctic's role pursued in global climate change. EOS, 80(35), 398-400.
Morgan, V.I., I.D. Goodwin, D.M. Etheridge and C.W. Wookey. 1991. Evidence from Antarctic ice cores for recent increases in snow accumulation. Nature, 354(6348), 58-60.

Mosley-Thompson, E. and 6 others. 1995. Recent increase in South Pole snow accumulation. Ann. Glaciol., 21, 131-138.

Mosley-Thompson, E., J.F. Paskievitch, A.J. Gow and L.G. Thompson. 1999. Late 20th century increase in South Pole snow accumulation. J. Geophys. Res., 104(D4), 3877-3886.

Mulvaney, R., D. Wagenbach and E. Wolff. 1998. Postdepositional change in snowpack nitrate from observation of year-round nearsurface snow in coastal Antarctica. J. Geophys. Res., 103(D9), $11,021-11,031$.

Oerter, H., W. Graf, F. Wilhelms, A. Minikin and H. Miller. 1999. Accumulation studies on Amundsenisen, Dronning Maud Land, by means of tritium, dielectric profiling and stable-isotope measurements: first results from the 1995-96 and 1996-97 field seasons. Ann. Glaciol., 29, 1-9.

Palais, J.M., I.M. Whillans and C. Bull. 1982. Snow stratigraphic studies at Dome C, East Antarctica: an investigation of depositional and diagenetic processes. Ann. Glaciol., 3, 239-242.

Parish, T.R. and D.H. Bromwich. 1991. Continental-scale simulation of the Antarctic katabatic wind regime. J. Climate, $\mathbf{4}(2)$, 135-146.

Petit, J.R., J. Jouzel, M. Pourchet and L. Merlivat. 1982. A detailed study of snow accumulation and stable isotope content in Dome C (Antarctica). J. Geophys. Res., 87(C6), 4301-4308.

Pettré, P., J.F. Pinglot, M. Pourchet and L. Reynaud. 1986. Accumulation distribution in Terre Adélie, Antarctica: effect of meteorological parameters. J. Glaciol., 32(112), 486-500.

Picciotto, E., G. Crozaz and W. de Breuck. 1971. Accumulation on the South Pole-Queen Maud Land traverse, 1964-1968. In Crary, A.P., ed. Antarctic snow and ice studies II. Washington, DC, American Geophysical Union, 257-315. (Antarctic Research Series 16.)

Pourchet, M., J.F. Pinglot and C. Lorius. 1983. Some meteorological applications of radioactive fallout measurements in Antarctic snows. J. Geophys. Res., 88(C10), 6013-6020.

Proposito, M. and 9 others. 2002. Chemical and isotopic snow variability along the 1998 ITASE traverse from Terra Nova Bay to Dome C, East Antarctica. Ann. Glaciol., 35, 187-194.

Rémy, F., P. Shaeffer and B. Legrésy. 1999. Ice flow physical processes derived from ERS-1 high-resolution map of Antarctica and Greenland ice sheet. Geophys. J. Int., 139(3), 645-656.

Richardson, C. and P. Holmlund. 1999. Spatial variability at shallow snow-layer depths in central Dronning Maud Land, East Antarctica. Ann. Glaciol., 29, 10-16.

Richardson, C., E. Aarholt, S.E. Hamran, P. Holmlund and E. Isaksson. 1997. Spatial snow distribution mapped by radar. J. Geophys. Res., 102(B9), 20,343-20,353.

Schwander, J., J. Jouzel, C.U. Hammer, J.R. Petit, R. Udisti and E. Wolff. 2001. A tentative chronology for the EPICA Dome Concordia ice core. Geophys. Res. Lett., 28(22), 4243-4246.

Siegert, M.J. 2003. Glacial-interglacial variations in central East Antarctic ice accumulation rates. Quat. Sci. Rev., 22(5-7), 741-750.

Spikes, V.B., G.S. Hamilton, S.A. Arcone, S. Kaspari and P. Mayewski. 2004. Variability in accumulation rates from GPR profiling on the West Antarctic plateau. Ann. Glaciol., 39, 238-244.

Stenni, B. and 8 others. 1999. 200 years of isotope and chemical records in a firn core from Hercules Névé, northern Victoria Land, Antarctica. Ann. Glaciol., 29, 106-112.

Stenni, B. and 6 others. 2002. Eight centuries of volcanic signal and climate change at Talos Dome (East Antarctica). J. Geophys. Res., 107(D9), 4076. (doi: 10.1029/2000JD000317.)

Testut, L., I.E. Tabacco, C. Bianchi and F. Rémy. 2000. Influence of geometrical boundary conditions on the estimation of rheological parameters. Ann. Glaciol., 30, 102-106. 
Torinesi, O., M. Fily and C. Genthon. 2003. Variability and trends of summer melt period of Antarctic ice margins since 1980 from microwave sensors. J. Climate, 16(7), 1047-1060.

Traversi, R., S. Becagli, E. Castellano, O. Largiuni and R. Udisti. 2000. Stability of chemical species in firn layers from Antarctica. In Colacino, M. and G. Giovannelli, eds. 8th Workshop, Italian Research on the Antarctic Atmosphere. Proceedings. Vol. 69. Bologna, Società Italiana di Fisica, 421-443.

Traversi, R. and 7 others. 2004. Spatial and temporal distribution of environmental markers from coastal to plateau areas in Antarctica by firn core chemical analysis. Int. J. Environ. Anal. Chem., 84(6-7), 457-470. (doi: 10.1080/03067310310001640393.)

Udisti, R., S. Bellandi and G. Piccardi. 1994. Analysis of snow from Antarctica: a critical approach to ion-chromatographic methods. Fresenius' J. Anal. Chem., 349(4), 289-293.

Udisti, R. and 6 others. 2000. Holocene electrical and chemical measurements from the EPICA-Dome C ice core. Ann. Glaciol., 30, 20-26.

Udisti, R. and 8 others. 2004. Stratigraphic correlations between the European Project for Ice Coring in Antarctica (EPICA) Dome $\mathrm{C}$ and Vostok ice cores showing the relative variations of snow accumulation over the past $45 \mathrm{kyr}$. J. Geophys. Res., 109(D8), D08101. (doi: 10.1029/2003JD004180.)

Urbini, S., S. Gandolfi and L. Vittuari. 2001. GPR and GPS data integration: examples of application in Antarctica. Ann. Geofis., 44(4), 687-702.

Van den Broeke, M.R. and 6 others. 1999. Climate variables along a traverse line in Dronning Maud Land, East Antarctica. J. Glaciol., 45(150), 295-302.

Van der Veen, C.J. and J.F. Bolzan. 1999. Interannual variability in net accumulation on the Greenland ice sheet: observations and implications for mass balance measurements. J. Geophys. Res., 104(D2), 2009-2014.
Vaughan, D.G., H.F.J. Corr, C.S.M. Doake and E.D. Waddington. 1999. Distortion of isochronous layers in ice revealed by ground-penetrating radar. Nature, 398(6725), 323-326.

Vincent, C. and M. Pourchet. 2000. Geodetic measurements and accumulation rate at Dome Concordia, December 1999 and January 2000. Grenoble, Laboratoire de Glaciologie et Géophysique de l'Environnement. Institut Français pour la Recherche et la Technologie Polaire and Ente per le Nuove Tecnologie, I'Energia e l'Ambiente. (Technical report.)

Vittuari, L. and 6 others. 2004. Space geodesy as a tool for measuring ice surface velocity in the Dome $\mathrm{C}$ region and along the ITASE traverse [030626.]. Ann. Glaciol., 39, 402-408.

Waddington, E.D., J. Cunningham and S.L. Harder. 1996. The effects of snow ventilation on chemical concentrations. In Wolff, E.W. and R.C. Bales, eds. Chemical exchange between the atmosphere and polar snow. Berlin, etc., Springer-Verlag, 403-451.

Wagnon, P., R.J. Delmas and M. Legrand. 1999. Loss of volatile acid species from upper firn layers at Vostok, Antarctica. J. Geophys. Res., 104(D3), 3423-3431.

Wendler, G., J.C. André, P. Pettré, J. Gosink and T. Parish. 1993. Katabatic winds in Adélie coast. In Bromwich, D.H. and C.R. Stearns, eds. Antarctic meteorology and climatology: studies based on automatic weather stations. Washington, DC, American Geophysical Union, 23-46. (Antarctic Research Series 61.)

Whillans, I.M. 1975. Effect of inversion winds on topographic detail and mass balance on inland ice sheets. J. Glaciol., 14(70), 85-90.

Wolff, E.W. 1996. Location, movement and reactions of impurities in solid ice. In Wolff, E.W. and R.C. Bales, eds. Chemical exchange between the atmosphere and polar snow. Berlin, etc., Springer-Verlag, 541-560.

MS received 2 March 2004 and accepted in revised form 14 November 2004 